\title{
Introduction to Democracy as a Form of Life
}

\section{Ana Honnacker and Magnus Schlette}

\section{CpenEdition}

\section{Journals}

Electronic version

URL: http://journals.openedition.org/ejpap/2081

DOI: 10.4000/ejpap.2081

ISSN: 2036-4091

\section{Publisher}

Associazione Pragma

Electronic reference

Ana Honnacker and Magnus Schlette, «Introduction to Democracy as a Form of Life », European Journal of Pragmatism and American Philosophy [Online], XII-2 | 2020, Online since 14 December 2020, connection on 15 December 2020. URL : http://journals.openedition.org/ejpap/2081 ; DOI : https:// doi.org/10.4000/ejpap.2081

This text was automatically generated on 15 December 2020.

\section{c)}

Author retains copyright and grants the European Journal of Pragmatism and American Philosophy right of first publication with the work simultaneously licensed under a Creative Commons AttributionNonCommercial-NoDerivatives 4.0 International License. 


\title{
Introduction to Democracy as a Form of Life
}

\author{
Ana Honnacker and Magnus Schlette
}

1 Nowadays, Western societies find themselves in a situation that has been coined as a "crisis of representation" or even as "postdemocracy." ${ }^{1}$ The self-understanding of western societies that is informed by the idea of its citizen's democratic participation in the shaping of the common good has been severely tested by a growing disenchantment with politics. This expresses itself not only in a growing disinterest in common decision-making but also in an ominous interplay between a decreasing willingness to overcome disagreements in procedures of discursive rapprochement and an emotionally impregnated polarization of political opinions. The cohesiveness of the public sphere as a realm of reciprocal recognition through the exchange of perspectives, expectations and convictions on the basis of a shared consciousness of civic commonality seems to be on the decline. This publication intends to assess the potential contributions to political thought of classical and contemporary pragmatist theory in conceptualizing the prerequisites of democratic society. The classical pragmatist's reflection on democratic society was itself embedded in a situation of enduring political crisis caused by a process of rapid modernization. Pragmatist susceptibility to contemporary issues was confronted with democratic issues from the start and pragmatism has contributed several insights to democratic thinking.

2 The concept of "life-form" shall denote the fact that these insights concern factors antecedent to political action and thereby transcend the field of democratic theory in the strict sense. Firstly, these factors encompass dispositional attitudes of leading one's life and particularly of establishing reciprocal relationships with fellow citizens, which promote cooperation in the body politic and facilitate the mediation between individual and common goods; pragmatists think about history and future, nature and education, about truth and knowledge, art and religion, freedom and obligation in terms of how they would have to be designed in order to locate their objects within a democratic social body. Secondly, they impregnate the various functional spheres of society and the logic of communication in these spheres - not only the political sphere, 
but also other spheres such as science, religion and the economy. A common denominator of pragmatist thought about these diverse topics is the furtherance of a situation-sensitive attitude that allows the continual reassessment of the practical impacts of our socially gathered convictions in order to adapt new and unforeseen experiences. And it invests a great deal of reflection on the conditions under which this attitude may develop and flourish in a socially productive and creative way. The following series of essays contributes to this reflection from different, but mutually complementary sides.

3 According to Pape's essay "Sharing and the Democratic Form of Human Life. How to Reconstruct Peirce's Metaphysics of Agapasm, Rhetoric and the Interactional Basis of Democracy," as a symbolic species man provides a basis for some features of democratic communication and political processes; the potential of democratic cooperation is intrinsic to the form of symbolic communication that has been established as a primary source of human-specific intersubjectivity. Following Pape there is something implicit in Peirce's thought about signs, human beings and the interpersonal relations constituting the fabric of society, that fosters the development of democratic life-forms: The self-understanding of human beings is to a large extent constituted by the compulsion and forces of human life that are shared and enable dialogical interactions. In particular, assertions and other complex linguistic signs allow for exchanges about communal, political, and other general issues. They both presuppose, change and create a common access to relational experience for the community of interpreters.

4 Heidi Salaverría observes a lack of openness to productive dissent in contemporary society and she calls for the political relevance to cultivate imaginative doubt as a habit of critical common sense. According to Salaverría, this is where pragmatism kicks in: Pragmatism appeals to common sense, says Salaverría, that may serve as a critical alternative to deformed models of community which are unable to digest doubt. Peirce, James, and Dewey brought the productive tension between doubting and the development of new convictions into the focus of political philosophy. In her contribution "Vague Certainty, Violent Derealization, Imaginative Doubting. Reflections on Common Sense and Critique in Peirce and Butler" Salaverría is particularly interested in the transformation from doubt to abduction and the emergence of new hypotheses in the discourse about the common good.

Whereas Salaverría defends a concept of productive dissent for the furtherance of democratic society, Mara-Daria Cojocaru asks how society shall deal with violent disagreement. In her contribution "Turn Anger into Passionate Disagreement? A Pragmatic Proposal" Cojocaru says that the two currently most widely held philosophical views of anger have arrived at an impasse. They cannot see beyond anger as a potentially violent kind of disagreement and only diverge on whether to endorse or reject violence. Consequently, they run the risk of either jeopardizing the respective moral and political consensus - going down the spiral in which anger is met with anger - or of taming anger before the relevant moral and political questions are asked. In contrast to these approaches and with reference to the dynamic conceptualization of affective states found in the works of Peirce and Dewey, she highlights the epistemic benefits of anger in situations of moral and political conflict. These benefits are particularly important if conflicts of value arise within a democratic body and have to be cooperatively assessed and processed. She suggests a way of dealing with anger that 
turns violent disagreement into one that is passionate and particularly important if we want to account for conflicts of value comprehensively.

Another feeling which indicates injustices, oppressive relations and other problematic constellations is addressed by Katrin Wille in her essay "Unease as a FeministPragmatist Concept. Conceptualizing a Powerful Sentiment along with Charlotte Perkins Gilman." Following the work of pragmatist thinker Gilman, Wille explores the potentials of the feeling of unease to reveal undemocratic conventions and mobilize political forces. Unease, Wille says, both in its habitualized and situational manifestations, may function as basis for critical analysis. In order to theorize the idea, the Deweyan concepts of habit and quality are taken into consideration.

With Matthias Jung's essay, "Science as a Democratic Life-Function and the Challenge of Scientism," the focus shifts from investigating the dispositional attitudes of leading one's life and particularly of establishing reciprocal relationships with fellow citizens which promote cooperation in the body politic, to a consideration of particular functional spheres in society and their role for democratic societal organization. Jung's essay reflects how comprehensive worldviews either further or hinder the democratic ideal of all-inclusive experience; he particularly focusses on the role science plays in establishing worldviews in a democratic society.

8 Whereas Jung deals with the contribution of science to a comprehensive worldview that may either further or hinder democratic cooperation, Magnus Schlette's essay "Democracy and Political Religion" focusses on Dewey's conceptualization of a "common faith" and the role he has ascribed to religion for the furtherance of progress in democratic societies. Schlette takes Dewey's account of religion into consideration from the perspective of Reinhold Niebuhr's criticism of Dewey. According to Niebuhr, Dewey establishes a concept of civil religion that is not sufficient to do justice to the validity claims of positive religions and downplays their role within society. The confrontation of Dewey and Niebuhr helps Schlette enlarge upon the question to which extent religions may be integrated into the democratic project of fundamentally secularized modern societies.

9 Dirk Jörke's and Philipp Wagenhals' contribution "Methodologies Matter: From Axel Honneth's Conservatism to John Dewey's Radicalism" focuses on the correlation of democracy and economy and presents Dewey's turn toward democratic socialism - as it has been coined by Robert Westbrook as an alternative to Honneth's reformism. It is occupied with the methodological layout of their respective systems of thought: Dewey's problem-solving approach and Honneth's normative reconstruction. Honneth's reception of Dewey's experimentalism, Jörke and Wagenhals argue, does not tap the latter's full potential. In a rigorous examination of Dewey's method, a far more radical call is highlighted: the re-evaluation of fundamental principles of liberal democracies such as private property. According to Dewey, individual freedom and growth can only be realized by democratizing economic processes as far as possible, thereby relying on scientifically guided modes of experimentation.

10 The need to democratize economic processes is nowhere more obvious then in environmental issues. The way we deal with our environment, especially with essential resources like air, water and soil, affects not only our possibilities of growth and selffulfillment, but in the long run even the very conditions for our bare survival. For Ana Honnacker it is striking that even from within environmentalist circles democracy is often considered to be a hindrance to good environmental politics. Her essay 
"Environmentalism and Democracy: Pragmatist Perspectives on a Precarious Relation" argues that the global environmental challenge can only be met, if it is conceived as a cooperative task that requires a high level of creative problem-solving and of reconciling interests and needs. Consequently, environmentalists should strive to deepen and foster the democratic attitude. Looking at the "green departures" from democratic grounds, Honnacker says, is helpful in building an "ecological democracy" that incorporates pragmatic insights.

11 In order to explore the idea of democracy as a form of life, a working group of pragmatist scholars of diverse disciplines met over three years at the FEST Heidelberg and the FIPH Hannover. Guest scholars like Michael Raposa or Philip Kitcher contributed their expertise to the ongoing discussion and collaboration which finally resulted in the founding of the German Pragmatism Network. The following collection of essays documents the variety of perspectives and insights that forgathered in the course of our common research activities on a topic that remains to be pressing.

\section{NOTES}

1. On Behalf of the German Pragmatism Network.

\section{AUTHORS}

\section{ANA HONNACKER}

Universität Hildesheim

post[at]ana-honnacker.de

MAGNUS SCHLETTE

Universität Heidelberg

magnus.schlette[at]fest-heidelberg.de 